\title{
SOME EXPERIMENTAL OBSERVATIONS CON- CERNING THE BEHAVIOR OF VARIOUS BEES IN THEIR VISITS TO COTTON BLOSSOMS. II
}

\author{
H. A. ALLARD
}

U. S. Department of Agriculture

Experiment No. 21.--July 29. Observations continued one half hour, from 1:30 to 2:00 P.M. Three blossoms arranged in the same row.

(a) Control. Normal American upland cotton blossom pinned in position.

(b) Control. Normal American upland cotton blossom pinned in position.

(c) Hawasaki blossom entire pinned in position.

DAta For Experiment No. 21

\begin{tabular}{|c|c|c|c|c|c|c|c|c|c|c|c|c|c|c|}
\hline \multirow{2}{*}{ 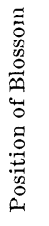 } & \multirow[b]{2}{*}{ 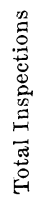 } & \multicolumn{6}{|c|}{ Distribution by Species } & \multirow[b]{2}{*}{ 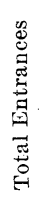 } & \multicolumn{6}{|c|}{ Distribution by Species } \\
\hline & & 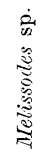 & 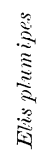 & 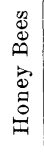 & 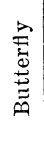 & 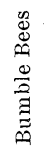 & 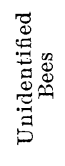 & & 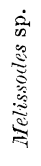 & 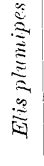 & 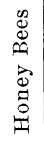 & 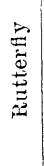 & $\begin{array}{l}0 \\
0 \\
0 \\
0 \\
0 \\
0 \\
0 \\
0 \\
0\end{array}$ & 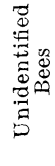 \\
\hline $\begin{array}{l}(a) \\
\text { (b) } \\
(c)\end{array}$ & $\begin{array}{r}12 \\
9 \\
11\end{array}$ & $\begin{array}{r}10 \\
6 \\
8\end{array}$ & & $\begin{array}{l}2 \\
3 \\
2\end{array}$ & 1 & & & $\begin{array}{l}1 \\
2 \\
2\end{array}$ & 1 & & $\begin{array}{l}1 \\
2\end{array}$ & 1 & & \\
\hline
\end{tabular}

Experiments 18, 19, 20 and 21 are essentially similar, since in each a blossom of the Asiatic cotton, Hawasaki, is compared with American upland blossoms. The points of location of the blossoms were unchanged throughout, but the blossoms themselves were interchanged in order to check any advantage which might obtain from a particular position in the arrangement.

The Hawasaki blossom is smaller in size than the upland and much brighter yellow in color with conspicuous deep reddish purple petal spots inside. It was thought 668 
that the behavior of visiting bees toward the American upland blossoms and the dissimilar Asiatic Hawasaki would perhaps serve to distinguish between the effects of color and form as compared with odor in inducing the visits of bees into cotton blossoms. Results indicate that the Hawasaki blossom, although quite unfamiliar to our native bees, is nearly as frequently inspected as our American upland blossoms.

From the readiness with which bees are led to inspect the Hawasaki blossoms, single detached cotton petals and the white convolvulus blossom even after it had become greatly wilted and collapsed, it is evident that they are not at first sight led to distinguish cotton blossoms from other blossoms, etc., by their characteristic form and color alone. Only by a nearer approach does the process of inspection become more discriminating in its nature with regard to the kind of blossom.

Experiment No. 22.- July 29. Period of observation one half hour, from $2: 10$ to $2: 40$ P.M. Two blossoms were used on two adjacent plants in the same row and similarly exposed.

(a) Blossom of American upland which had opened the day before and in consequence had become deep reddish purple in color.

(b) Control. Normal, recently opened cream-colored blossom of same variety.

DATA FOR EXPERIMENT No. 22

\begin{tabular}{|c|c|c|c|c|c|c|c|c|c|c|c|c|}
\hline \multirow[b]{2}{*}{ 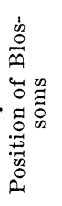 } & \multirow[b]{2}{*}{ 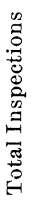 } & \multicolumn{5}{|c|}{ Distribution by Species } & \multirow[b]{2}{*}{ 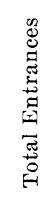 } & \multicolumn{5}{|c|}{ Distribution by Spepies } \\
\hline & & 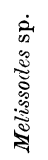 & 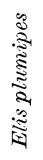 & 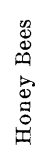 & 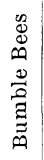 & 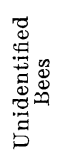 & & 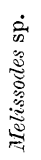 & 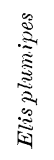 & 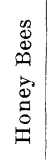 & 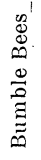 & 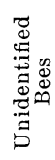 \\
\hline $\begin{array}{l}(a) \\
(b)\end{array}$ & $\begin{array}{l}12 \\
26\end{array}$ & $\begin{array}{l}11 \\
24\end{array}$ & & & 2 & 1 & 1 & 1 & & & & \\
\hline
\end{tabular}

Some time after midday, depending upon prevailing weather conditions, the recently expanded cream-colored cotton blossoms of that day slowly begin to close again and assume a reddish color, which by the second day is a 
deep reddish purple: In connection with previous observations it was noted that those older blossoms appeared to possess little attractiveness for bees. The test was designed to reveal any differences which might serve to indicate to the bees that the purple blossom had passed the stage of usefulness to them. Although bees may in their flight indicate that the red blossom has been perceived, the inspections are usually far briefer than with the newly open blossoms of the same day. Rarely does a bee noticeably check its flight to hover over the red blossoms in the careful manner that it usually inspects those newly opened blossoms which are unchanged in color. The marked difference in color or some peculiarity of odor seems to inform the bees that an old blossom has nothing to offer them, since the pollen has been scattered and nectar is no longer secreted.

Experiment No. 23.- July 30. Time of observation one half hour, from 9:00 to 9:30 A.m. Three blossoms are arranged in the same row in equally exposed positions, as in previous experiments.

(a) Control. Normal upland cotton blossom pinned in position.

(b) Control. Normal upland cotton blossom pinned in position.

(c) Normal upland cotton blossoms with a drop or two of honey at base of petals within.

DATA FOR EXPERIMENT No. 23

\begin{tabular}{|c|c|c|c|c|c|c|c|c|c|c|c|c|}
\hline \multirow[b]{2}{*}{ 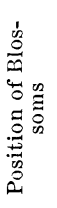 } & \multirow{2}{*}{ 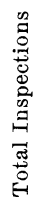 } & \multicolumn{5}{|c|}{ Distribution by Species } & \multirow[b]{2}{*}{ 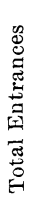 } & \multicolumn{5}{|c|}{ Distribution by Species } \\
\hline & & 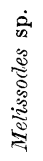 & 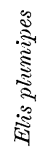 & 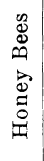 & 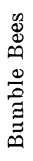 & 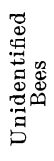 & & 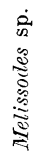 & 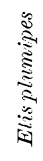 & 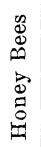 & 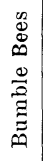 & 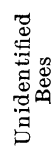 \\
\hline $\begin{array}{l}(a) \\
(b)\end{array}$ & $\begin{array}{l}7 \\
6\end{array}$ & $\begin{array}{l}5 \\
2\end{array}$ & & 1 & $\begin{array}{l}1 \\
2\end{array}$ & $\begin{array}{l}1 \\
1\end{array}$ & $\begin{array}{l}1 \\
1\end{array}$ & & & & $\begin{array}{l}1 \\
1\end{array}$ & \\
\hline (c) & 7 & 4 & & 1 & 1 & 1 & 2 & 1 & & 1 & & \\
\hline
\end{tabular}

The presence of a small quantity of honey in the blossom at (c) has not noticeably increased the number of entrances into it. 
The single Melissodes which entered the blossom at (c) gave evidence of its appreciation of the honey which it discovered by stubbornly refusing to leave the blossom until rather violently brushed away.

Experiment No. 24.-July 30. Time of observations one half hour, from 11:00 to 11:30 A.M. Three blossoms arranged in same row. This experiment is an exact repetition of the preceding.

(a) Control. Normal upland cotton blossom pinned in position.

(b) Control. Normal upland cotton blossom pinned in position.

(c) Normal blossom with honey at base within.

DAtA FOR EXPERIMENT No. 24

\begin{tabular}{|c|c|c|c|c|c|c|c|c|c|c|c|c|}
\hline \multirow{2}{*}{ 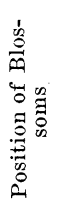 } & \multirow{2}{*}{ 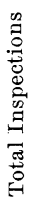 } & \multicolumn{5}{|c|}{ Distribution by Species } & \multirow[b]{2}{*}{ 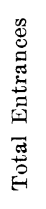 } & \multicolumn{5}{|c|}{ Distribution by Species } \\
\hline & & 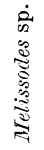 & 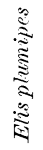 & 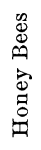 & 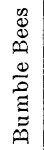 & 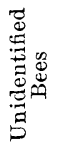 & & 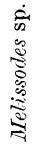 & 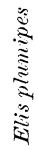 & 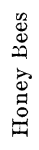 & 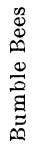 & 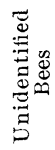 \\
\hline (a) & 26 & 16 & 2 & 4 & 3 & 1 & 7 & 3 & 2 & & 2 & \\
\hline (b) & 33 & 22 & 2 & 5 & 3 & 1 & 8 & & 2 & 3 & 3 & \\
\hline (c) & 14 & 9 & 1 & 3 & 1 & & 0 & & & & & \\
\hline
\end{tabular}

Experiment No. 25.- July 30. Time of observations one half hour, from 11:30 to 12:00 A.M. Three blossoms arranged in the same row.

(a) Normal cotton blossoms pinned in position as a control.

(b) Normal cotton blossom with honey added at base of petals within.

DATA FOR EXPERIMENT No. 25

\begin{tabular}{|c|c|c|c|c|c|c|c|c|c|c|c|c|}
\hline \multirow{2}{*}{ 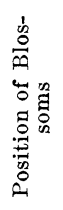 } & \multirow{2}{*}{ 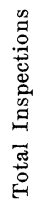 } & \multicolumn{5}{|c|}{ Distribution by Species } & \multirow[b]{2}{*}{ 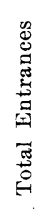 } & \multicolumn{5}{|c|}{ Distribution by Species } \\
\hline & & 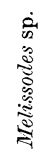 & 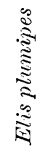 & 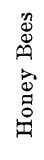 & 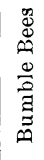 & 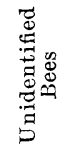 & & 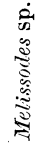 & 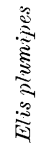 & 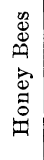 & 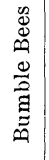 & 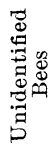 \\
\hline $\begin{array}{l}(a) \\
(b) \\
(c)\end{array}$ & $\begin{array}{l}22 \\
19 \\
15\end{array}$ & $\begin{array}{l}16 \\
14 \\
10\end{array}$ & & $\begin{array}{l}6 \\
4 \\
3\end{array}$ & $\begin{array}{l}1 \\
2\end{array}$ & & $\begin{array}{l}4 \\
1 \\
2\end{array}$ & & & $\begin{array}{l}4 \\
1 \\
1\end{array}$ & 1 & \\
\hline
\end{tabular}


(c) Normal cotton blossom pinned in position as a control.

During the forenoon the weather was dull, so that bees were less frequent in their visits.

Experiment No. 26.-August 1. Period of observations one half hour, from 9:00 to 9:30 A.M. Blossoms arranged in same row as follows:

(a) Normal cotton blossom with honey at base of petals within.

(b) Normal cotton blossom pinned in position as a control.

(c) Normal cotton blossom pinned in position as a control.

DATA FOR EXPERIMENT No. 26

\begin{tabular}{|c|c|c|c|c|c|c|c|c|c|c|c|c|}
\hline \multirow[b]{2}{*}{ 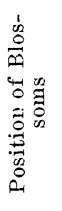 } & \multirow[b]{2}{*}{ 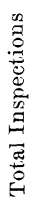 } & \multicolumn{5}{|c|}{ Distribution of Species } & \multirow[b]{2}{*}{ 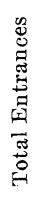 } & \multicolumn{5}{|c|}{ Distribution of Species } \\
\hline & & 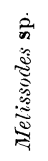 & 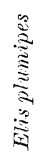 & 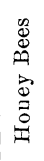 & 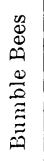 & 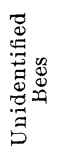 & & 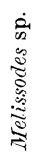 & 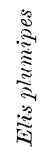 & 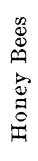 & 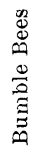 & 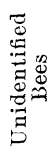 \\
\hline $\begin{array}{l}(a) \\
(b) \\
(c)\end{array}$ & $\begin{array}{l}26 \\
27 \\
20\end{array}$ & $\begin{array}{l}22 \\
22 \\
17\end{array}$ & 1 & $\begin{array}{l}1 \\
2\end{array}$ & $\begin{array}{l}1 \\
1 \\
1\end{array}$ & $\begin{array}{l}1 \\
2 \\
2\end{array}$ & $\begin{array}{l}0 \\
1 \\
1\end{array}$ & & & 1 & 1 & \\
\hline
\end{tabular}

Experiment No. 2\%.-August 1. Period of observations one half hour, from 9:00 to 9:30 A.M. Blossoms are arranged in the same row.

At (a) an unmutilated cotton blossom was pinned in position. Portions of cotton leaves were carefully cut out and fastened outside and within the blossom in such a manner as to extend just to the margin of the petals on both sides. In this way none of the yellow color of the petals remained visible. The stamen tube, pistil, etc., projected as in a normal blossom. The blossom was practically without petals, since these were not visible, although such odors as they may have possessed could still diffuse around the blossom. A drop or two of honey. was also added at the base of the petals within in order to make certain that agreeable odors were present, since 
these must now necessarily constitute the sole allurement.

At (b) normal blossom pinned in position. The tips of the petals were lightly smeared with honey.

At (c) control. Normal cotton blossom pinned in position.

DAta For Experiment No. 27

\begin{tabular}{|c|c|c|c|c|c|c|c|c|c|c|c|c|}
\hline \multirow[b]{2}{*}{ 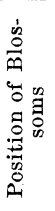 } & \multirow{2}{*}{ 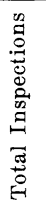 } & \multicolumn{5}{|c|}{ Distribution by Species } & \multirow[b]{2}{*}{ 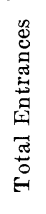 } & \multicolumn{5}{|c|}{ Distribution by Species } \\
\hline & & 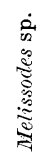 & 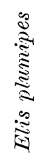 & 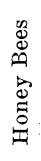 & 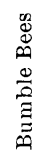 & 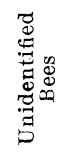 & & 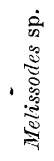 & 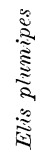 & 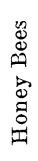 & 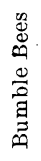 & 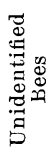 \\
\hline $\begin{array}{l}(a) \\
(b) \\
(c)\end{array}$ & $\begin{array}{r}0 \\
34 \\
25\end{array}$ & $\begin{array}{l}23 \\
14\end{array}$ & & $\begin{array}{l}10 \\
10\end{array}$ & $\begin{array}{l}1 \\
1\end{array}$ & & $\begin{array}{l}2 \\
6\end{array}$ & & & $\begin{array}{l}2 \\
6\end{array}$ & & \\
\hline
\end{tabular}

As shown in previous experiments, the removal of the petals no longer advertises a cotton blossom to the notice of bees. The same results are obtained when the petals are no longer visible, although still attached to the blossom as at $(a)$. It is natural to suppose that the presence of honey would add appreciably to the zone of alluring odors surrounding the blossom.

Without the conspicuous corolla to invite inspection, however, the bees are not led to approach sufficiently near to discover the blossom by its attendant odors alone. These results are not in agreement with some of the general conclusions of Plateau in his noteworthy memcirs: "Comment les fleures attirent les insectes." $\mathrm{He}$ states: "Les insectes visitent activement les inflorescences qui n'ont subi aucune mutilation mais dont la forme et les couleurs sont masquées par des feuilles vertes.",3 This would follow only when other attractive influences were actively operative, as various odors agreeable to bee visitors.

Experiment No. 28.-Angust 1. Time of observation one half hour, from $9: 30$ to 10:00 A.M. This experiment makes use of most of the material and the same positions of the preceding, with the changes as follows:

${ }^{3}$ Bulletin de l'Académie royale des Sciences, No. 11, November, 1895. 
(a) Outer leaf covering removed from the blossom used at $(a)$ in preceding experiment, thus making the outer surface of the petals visible. Honey at the base within, as before.

(b) Normal blossom pinned in position as a control. No honey has been added to this blossom.

(c) Normal blossom used in preceding experiment with petals removed.

DATA FOR EXPERIMENT No. 28

\begin{tabular}{|c|c|c|c|c|c|c|c|c|c|c|c|c|}
\hline \multirow[b]{2}{*}{ 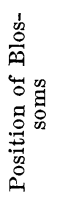 } & \multirow[b]{2}{*}{ 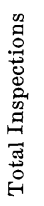 } & \multicolumn{5}{|c|}{ Distribution by Species } & \multirow[b]{2}{*}{ 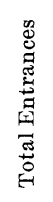 } & \multicolumn{5}{|c|}{ Distribution by Species } \\
\hline & & 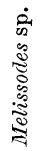 & 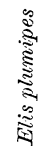 & 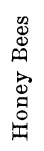 & 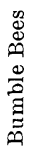 & 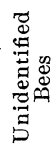 & & 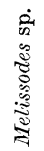 & 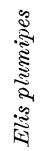 & 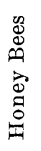 & 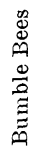 & 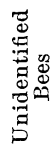 \\
\hline $\begin{array}{l}(a) \\
(b) \\
(c)\end{array}$ & $\begin{array}{r}9 \\
11 \\
1\end{array}$ & $\begin{array}{l}3 \\
4\end{array}$ & & $\begin{array}{l}6 \\
5 \\
1\end{array}$ & 1 & 1 & $\begin{array}{l}0 \\
1 \\
0\end{array}$ & & & 1 & & \\
\hline
\end{tabular}

By the removal of the outer covering of the blossoms at $(a)$, which in the previous experiment received no inspections, it became nearly or quite as attractive as the control at $(b)$. The blossom at $(c)$, however, no longer afforded means of attracting the bees. In this experiment and the previous one the corolla at $(a)$ was concealed with portions of cotton leaves to guard against introducing repellent odors which may have attended the use of any other material. In the course of this experiment the number of bees flying about became much reduced toward ten o'clock, although the day was clear, hot and sunny. The writer was even forced to postpone his observations for the remainder of the forenoon owing to the scarcity of visiting bees.

Experiment No. 29.-August 1. Period of observation one half hour, from 2:00 to 2:30 P.x. The material is arranged in the same row.

At (a) a cotton bud not due to open until the next morning had its petals quite fully pulled open so as to resemble a naturally opening blossom. 
At $(b)$ a second cotton bud due to open the next morning had its petals partly pulled open.

At (c) a normal cotton blossom growing in situ as a contro].

DAta For Experiment No. 29

\begin{tabular}{|c|c|c|c|c|c|c|c|c|c|c|c|c|}
\hline \multirow{2}{*}{ 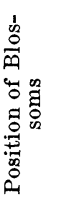 } & \multirow{2}{*}{ 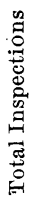 } & \multicolumn{5}{|c|}{ Distribution by Species } & \multirow[b]{2}{*}{ 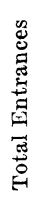 } & \multicolumn{5}{|c|}{ Distribution by Species } \\
\hline & & 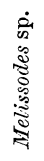 & 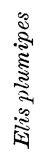 & 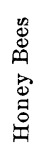 & 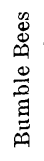 & 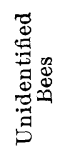 & & 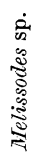 & 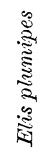 & 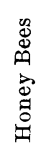 & 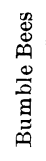 & 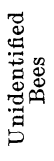 \\
\hline $\begin{array}{l}(a) \\
(b) \\
(c)\end{array}$ & $\begin{array}{r}15 \\
2 \\
24\end{array}$ & 5 & & $\begin{array}{r}10 \\
2 \\
20\end{array}$ & & & $\begin{array}{r}0 \\
0 \\
14\end{array}$ & & & 14 & & \\
\hline
\end{tabular}

In this experiment it was intended to observe the behavior of bees toward immature buds at $(a)$ and $(b)$ in comparison with fully expanded, mature blossoms. It was assumed that the former, owing to their immaturity, would perhaps prove less attractive to bees through the sense of smell than the fully matured blossoms. Although not definitely proved, it is reasonable to suppose that the processes of active nectar secretion simultaneously attend the unfolding of the petals and the shedding of the pollen. It would then follow that the odor of the unopened buds at $(a)$ and $(b)$ would prove less alluring than the blossom at $(c)$.

The yellow petals of the blossom at $(a)$ have served to invite frequent inspection, although at $(b)$ this is not as evident. This difference may depend upon the fact that the bud at (b) was much less conspicuous, since the petals have been only slightly pulled open. Whatever the true explanation, the mature, fully unfolded blossom which serves as a control at $(c)$ has received many more inspections, nearly 60 per cent. of which are actual entrances.

Experiment No. 30.-August 2. Period of observation one hour, from 9:30 to 10:30 A.m. Two blossoms were arranged in the same row in equally conspicuous positions.

At (a) a very clean, thin $5 \times 7$ glass plate was sup- 
ported in front of a fully opened cotton blossom pinned in position. The surrounding cotton leaves were then carefully drawn in closely around the plate so as to overlap the edges and most of the glass surface. In this arrangement, although the blossom was plainly visible through the glass, only a small portion of the glass surface remained in view.

At (b) control. A fully opened cotton blossom was pinned in position.

DAta for Experiment No. 30

\begin{tabular}{|c|c|c|c|c|c|c|c|c|c|c|c|c|}
\hline \multirow[b]{2}{*}{ 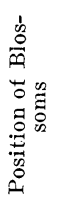 } & \multirow[b]{2}{*}{ 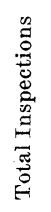 } & \multicolumn{5}{|c|}{ Distribution by Species } & \multirow[b]{2}{*}{ 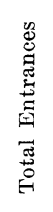 } & \multicolumn{5}{|c|}{ Distribution by Species } \\
\hline & & 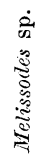 & 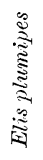 & 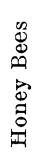 & 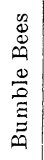 & 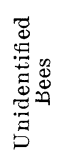 & & 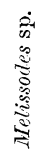 & 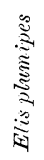 & 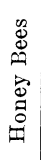 & 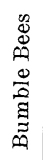 & 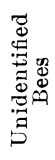 \\
\hline $\begin{array}{l}\text { (a) } \\
\text { (b) }\end{array}$ & $\begin{array}{l}18 \\
37\end{array}$ & $\begin{array}{r}6 \\
20\end{array}$ & 1 & $\begin{array}{l}3 \\
7\end{array}$ & $\begin{array}{l}4 \\
4\end{array}$ & $\begin{array}{l}5 \\
5\end{array}$ & $\begin{array}{l}0 \\
9\end{array}$ & & & 5 & 4 & \\
\hline
\end{tabular}

Of those bees which attempted to inspect the blossom at $(a)$, eight flew more or less forcibly against the glass, including two small unidentified bees, one Bombus sp., two honey bees and three Melissodes. One small bee tried persistently several times to fly through the glass toward the blossom just behind it. It is at once obvious that the blossom at (a) invited inspection by passing bees solely through the sense of sight.

Experiment No. 31.-August 9. Observations continued one hour, from 9:00 to 10:00 A.M.

Two blossoms were used in the same row as before. A box of thin wood was carefully constructed for this experiment. The dimensions were such that both cover and bottom were made of thin clear glass by using for each a $5 \times 7$ glass plate. These plates fitted tightly in lateral grooves. The box was about 4 inches deep, so that the end of a cotton branch together with its leaves and blossoms could be carefully pushed into a natural position within. By sliding the glass cover into place the box became practically air-tight. The blossom was plainly visible to passing bees, although any attractive 
odors which it diffused could no longer act as allurements. When placed in position among the cotton limbs the box and glass were almost completely concealed by drawing in and fastening around it a number of the surrounding leaves. This box enclosed the blossom at $(a)$.

At (b) control. A natural blossom pinned in position. The blossom at (a) received only two inspections, both by small, unidentified bees. The blossom at $(b)$ received only five inspections, three being by Melissodes and two by honey bees. There were no entrances at $(b)$.

Experiment No. 32.-August 9. Observations continued for one half hour, from 10 to 10:30 A.M. This experiment was identical with the preceding, except a third artificial blossom was added.

(a) Same blossom enclosed in the glass case as used at (a) in Experiment 31.

(b) The same control blossom pinned in position.

(c) An artificial paper blossom of crepe paper simulating a cotton blossom in color.

The blossom at (a) received one inspection by a Melissodes which hovered in front of the glass a few seconds only.

(b) Received eight inspections, which include two entrances by honey bees. The six inspections were entirely by Melissodes. Three bees inspected the artificial paper blossoms at $(c)$, including one each by a Melissodes, an unidentified bee, and a honey bee, which paused for a few seconds over the blossom but did not enter. During the last few days bee visitors have been rather too infrequent for satisfactory work, probably in part owing to the partly cloudy forenoons.

Experiment No. 33.-August 11. Observations continued for about one half hour, from 9:00 to $9: 30$ A.m. Three blossoms are arranged in a row.

At (a) three petals were placed in position on a leaf which was spread out flat and held between two thin clean $5 \times 7$ glass plates bound firmly together. This was placed in position among the branches of a plant and was nearly concealed by overlapping around it a number of cotton 
leaves. In this arrangement the yellow petal color still remained perceptible to the visual powers of bees.

At $(b)$ the detached petals of a cotton blossom were enclosed in a 250-c.c. graduated flask which was stoppered and fastened among the cotton leaves. The yellow petals were plainly visible through the clear thin glass of the flask.

At (c) a normal cotton blossom as a control.

(a) Received no inspections.

(b) Received one inspection by a honey bee which touched the flask.

(c) Received three inspections by honey bees. Two bees did not enter the blossom but alighted outside to get at the extra-involucral nectaries. During this experiment the bees were too infrequent visitors to make any results conclusive.

Experiment No. 34.-August 12. Time of observations 45 minutes, from $1: 30$ to $2: 15$ P.M. This experiment was an exact duplicate of the previous one.

(a) Petals of cotton blossom on a leaf between glass plates as at (a) in Experiment 33.

(b) Petals of cotton blossoms enclosed in a flask as at (b) in Experiment 33.

(c) Normal blossoms growing in situ as a control.

The blossom at (a) was twice inspected by Melissodes. The petals in the flask at $(b)$ were inspected two times by bees, once by a honey bee and once by a small, unidentified bee. The blossom at $(c)$ was inspected six times, including five entrances. One inspection was made by a small, unidentified bee, four entrances were by honey bees, and one entrance by a Melissodes.

For several days it was rather difficult to secure satisfactory data, as the bees were much less frequent visitors. The species of Melissodes, which were extremely common at the beginning of the experiments finally became far less common, although honey bees greatly increased. It is very interesting to note that many honey bees finally began to confine their visits solely to the outer involucral nectaries instead of entering the blos- 
soms. This change of habit seemed to become quite general at about the same period, for the writer noted it in all parts of the cotton field.

Throughout the period of observations the bees by their behavior and varying numbers showed themselves extremely sensitive to atmospheric changes, temperature relations, air movements, moisture, sunshine, etc. At times conditions even too obscure for human perception may have regulated their activities. The composition of the bee fauna to be observed in cotton fields shows much variation, depending upon the time of day, prevailing weather and seasonal influences. The position and exposure of the cotton field with relation to various local physiographic features, as type of soil, nearness to woods, swamps, hills and other crops also greatly influence the relative numbers and kinds of bees.

While carrying on his observations the writer noted that the bees, Melissodes, were exceedingly abundant among cotton grown on certain heavy, red-clay soils. These bees were much less abundant in fields on the lighter, sandy loams in some other localities. Honey bees are especially noticeable near bee trees or domestic hives. The marked abundance of other bees in particular localities likewise probably depends upon the proximity of the plants to their favorite breeding places.

Nectar glands are especially abundant on the cotton plant, including the leaves as well as the blossoms. The blossoms are supplied with several sets of nectaries. Cotton blossoms with their abundant supplies of readily accessible pollen and nectar and their open structure exclude few insect visitors. It follows that a considerable number of species of bees, wasps and other insects are at all times especially common visitors among cotton blossoms.

During the time the experiments previously described were in progress nearly 2,000 bees were observed to perceive, inspect or enter the blossoms and other material involved. 1,645 of these visits were distributed as follows : 1,381 or 83.9 per cent. were by species of Melis- 
sodes. 130 or 7.8 per cent. were by honey bees. 40 or 2.4 per cent. were by bumble bees. 83 or 5 per cent. were by various unidentified bees.

Eleven visits were made by Elis plumipes and one by a large butterfly. The size and yellow color of the petals serve to make cotton blossoms particularly conspicuous in contrast with their shaded background of dark green foliage. Once visiting insects have entered a cotton field, there is little doubt but that their visual powers almost wholly enable them to discover the blossoms. This is indicated by those experiments where the corolla of certain blossoms has been covered or entirely removed, since following this procedure the remaining portions of the blossoms were unvisited. The size and general appearance of cotton blossoms do not appear to be of great importance in initiating the process of inspection, since a single petal may receive as many inspections as the control. It is of interest to note in this connection that in experiments 14 and 15 the bees did not discriminate between the white convolvulus and cotton blossoms at least until after closer inspection. When such artificial material as cloth or paper was used, although the color more or less resembled cotton petals, the bees were rarely induced to inspect it closely. This discrimination may depend upon perceptible differences in color and texture rather than the presence of repellent odors which the material possessed. Many eminent observers have adduced a great deal of evidence which proves beyond doubt that bees develop keen powers of discernment in their associations with the structural details of different flowers.

The actual number of entrances into cotton blossoms is small in comparison with those instances when blossoms have been merely perceived or inspected. The writer's observations show that of 1,061 inspections of the control blossoms only 129, or 12.1 per cent., were actual entrances. One hundred and twenty of these entrances were distributed among the several kinds of bees, as follows : 45 , or 37.5 per cent., were by Melissodes; 
45 , or 37.5 per cent., were by honey bees ; 6 , or 5.0 per cent., were by Elis plumipes; 16, or 13.3 per cent., were by bumble bees; 8 , or 6.6 per cent., were by various small unidentified bees. A single entrance was made by a large butterfly.

Although it seems clear that the corolla of cotton blossoms invites the first approach of the bees through their visual sense, it is not so easy to determine the relative importance of the sense of sight and smell involved in their nearer inspections. Just why do so few bees decide to enter? In their careful inspection of a single petal or a suspicious blossom is the sense of sight alone involved? Except for a single Elis plumipes, no bee has ever alighted upon detached cotton petals, although these have served to attract attention quite as often as the control blossoms. It is not unusual, however, for the bees to inspect these structures very intently, almost touching the surface in their movements over them. The bees have just as persistently refused to enter all artificial blossoms or blossoms mutilated by removing a part or all of the petals. In experiment 6 a bee was completely deceived by the unreal structure at $(c)$ made to simulate an expanding bud by the use of actual cotton petals and portions of a cotton leaf. In this instance the bee inspected and finally squeezed itself down between the petals. Unless the fresh petals themselves possess a characteristic odor, odors such as might emanate from a normal blossom were entirely lacking and, therefore, could not have induced the bee to enter. Plateau concludes that visual conspicuousness by means of bright colors is of no advantage whatever to blossoms so far as insect visitors are concerned. He claims that if in nature all blossoms were green like the surrounding foliage, they would be just as readily discovered by bees and other insects in virtue of their odor. The writer's experiments in the field indicate that conspicuousness in virtue of their position and yellow coloration is a very important factor in leading bees and other insects to perceive cotton blossoms. 
It does not appear that the addition of small quantities of honey either upon the petals themselves or at the base of the flower within appreciably increased the inspections or entrances, although if a bee chanced to discover this honey, its fondness for it was evinced by its strong reluctance to leave.

It is probable that the inspections are largely of a visual nature, though these may be supplemented by certain odors when the blossoms are more closely examined. Many noted observers, especially Müller, have adduced abundant evidence to prove that the visual power of bees becomes very critical in their behavior toward minute differences of floral structure.

The bee Melissodes bimaculata, which is probably by far the commonest of this genus in certain cotton fields at Thompson's Mills, behaves somewhat differently from other bees in its inspections. Its flight is swift and irregular, and its entrance into a blossom is usually preceded by a more careful examination than that resorted to by bumble bees, the common honey bee, or the wasp Elis plumipes. It is the usual procedure for the last to fly straight into a blossom or almost drop into it from above, apparently without troubling itself about any preliminary examination. The bumble bees too are less fastidious in their closer inspection.

Many instances are recorded which illustrate the habit of bees to profit by previous successful or unsuccessful experiences. A sort of memory by association is developed so that older, more experienced bees often appear to work among blossoms to much better advantage than younger bees. As an illustration of the influence of previous association upon subsequent behavior, the writer cites the following interesting instance which has come under his observation at Thompson's Mills, North Georgia. It has been mentioned that the common honey bee sooner or later discovers the outer involucral nectaries of cotton blossoms and visits them very constantly, seemingly in preference to the inner floral 
nectaries. These particular nectaries, although present in our common American cottons, are never found on the Asiatic cottons, Hawasaki, etc. In the writer's variety tests these foreign cottons have been grown side by side and sometimes intermingled in the rows with the American cottons. The honey bees, in passing from blossom to blossom, visiting each time the outer involucral nectaries occasionally met the Asiatic variety. The previous association with the American cottons and their outer involucral nectaries led these bees to visit without success similar structures of the unfamiliar Asiatic variety. The bees quickly recognized their error after alighting and left the blossoms. Is this procedure other than the working of an associative memory? The writer is of the opinion that the honey bees do not discover these extra-floral nectaries until after more or less association with cotton blossoms each summer. This habit of the honey bee appears to become more noticeable later in the season. During the season of 1908 it appeared to be very general. It is a habit which seems to be almost wholly confined to honey bees.

These visits of the bees to the outer basal portion of the Asiatic cotton blossoms indicate that the visual powers alone were employed throughout the process. Although the bees first discovered the blossoms by their conspicuous petals, it is evident that they were led to search for outer involucral nectaries on the Asiatic cotton blossoms solely by their familiarity with the general form and structure of cotton blossoms.

As an illustration of associative memory this behavior of the honey bees is exactly similar to the behavior of certain bees in experiments conducted by Pérez ${ }^{ \pm}$, who used scarlet pelargoniums which are not visited by bees, since those flowers possess no nectar. He added honey to certain flowers which were then visited by bees, and says :

"Pérez, J., "Notes Zoologiques" (Actes de la Société Linnéenne de Bordeanx, Vol. XLVII, série V, tome VII, pp. 250-251, 1894). 
La couleur écarlate s'était si bien associée dans leur souvenir à l'idée du miel, qu'elles se passaient à la fin sur des fleurs de cette couleur n'en ayant pas reçu, et ne les quittaient qu' apres s'être assurées, par un examen scrupuleux et persistant, qu'elles n'avaient rien à $\mathrm{y}$ recueillir.

A translation of his own words follows: "Scarlet color and honey had become so closely associated in their minds that they finally alighted upon flowers of the same color which had received none, and would not leave until they had assured themselves by a scrupulous and persistent examination that these flowers had nothing to offer them.' Plateau gets precisely the same results when he says:

Lorsque l'insecte avait ainsi absorbé le liquide d'un certain nombre defleurs miellees, il lui arrivait de se diriger vers les Pelargoniums non nunis de miel. ${ }^{5}$

"After the insects had gathered honey from a number of flowers to which it had been added, they were then led to visit Pelargonium blossoms which had not received it." These observations are hardly in agreement with the rather radical conclusions of Bethe $^{6}$ that bees are devoid of sense impressions, and are incapable of profiting by previous experiences, that their activities are purely reflex, mechanical. Forel, Wasman, ButtelReepen, Huber and others have shown, nevertheless, that bees do profit by previous experiences and form habits under certain conditions. Lovell ${ }^{7}$ has shown that once bees have been accustomed to visiting a certain color, they tend to return to it regularly until it is to their advantage to change. Once the bees have entered the cotton fields, it is quite obvious that they are led to discover the blossoms by the conspicuous corolla. It would be interesting to learn just how they find the fields themselves. Although a single cotton blossom does not

'Bulletin de l'Academie royale de Belgique, 3e série, 33, January, 1897.

${ }^{6}$ Bethe Albrecht, "Durfen wir Ameisen und Beinen psychische Qualitäten zuschrieben?"' in Arch. f. d. ges. Physiologie, Bd. 70, 1898.

${ }^{7}$ Lovell, John H., "The Color Sense of the Honey Bee: Can Bees Distinguish Color's?', Amer. Nat., Vol. 'XLIV, No. 527, November, 1910. 
seem especially odoriferous, it is not improbable that a field of well-developed cotton plants may readily advertise its location to the olfactory sense of bees by odoriferous clouds, so to speak, which are wafted away with every air-movement. During a hot, sunny afternoon the combined odors volatilizing from the great numbers of foliage and floral nectaries, the pollen, etc., must be very considerable. Especially during clear sunny days following periods of cloudy or rainy weather bees become unusually active and numerous. Many of these visitors have no doubt learned the location of the fields by previous association. 